\title{
Рівень циркулюючих імунних комплексів у хворих на дифузний токсичний зоб за умов лікування радіойодом
}

\section{H.M. Cтепypa,}

\section{Г.А. Замотаєва,}

\section{І.П. Волинець}

ДУ «Інститут ендокринології та обміну речовин ім. В.П. Комісаренка НАМН України»

\begin{abstract}
Резюме. Дифузний токсичний зоб - автоімунне захворювання, обов'язковими ознаками якого є стійка підвищена продукція тиреоїдних гормонів і дифузне збільшення щитоподібної залози (Щз) різного ступеня. Причинами розвитку дифузного токсичного зоба (ДТЗ) $є$ автоімунні процеси, тобто формування агресії антитіл проти тканини власної ЩЗ. Мета роботи - визначення впливу радіойодотерапії на вміст циркулюючих імунних комплексів (ЦІК) у хворих на тиреотоксикоз. Матеріал і методи. Визначали кількість ЦІК у 34 хворих на ДТЗ (хворобу Грейвса) та в 49 пацієнтів із тиреоїдний раком (група порівняння). Вимірювали рівні ЦІК напередодні, через 6 днів, 1 і 6 місяців після введення радіойоду. Результати. У пацієнтів із тиреотоксикозом після введення йоду-131 кількість ЦІК протягом усього періоду обстеження практично не змінювалась. У хворих на рак ЩЗ введення лікувальних активностей йоду-131 спричинило зростання вмісту ЦІК із максимальним рівнем через 1 місяць після введення. Висновки. Різниця вмісту ЦІК після радіойодотерапії у хворих на ДТЗ і тиреоїдний рак, вочевидь, $є$ наслідком введення різних доз йоду-131: хворі з тиреотоксикозом отримували радіойод, активність якого була в межах від 380 МБк до 784 МБк, тоді як активність йоду-131 у хворих на рак Щ3 була значно більшою — від 2640 МБк до 6000 МБк.
\end{abstract}

Ключові слова: дифузний токсичний зоб, тиреотоксикоз, рак щитоподібної залози, радіойодотерапія, йод-131, циркулюючі імунні комплекси.

Дифузний токсичний зоб (ДТЗ) є найпоширенішим автоімунним захворюванням щитоподібної залози (ЩЗ), за якого відбувається

* Адреса для листування (Correspondence): ДУ «Інститут ендокринології та обміну речовин ім. В.П. Комісаренка НАМН України», вул. Вишгородська, 69, м. Київ, 04114 Україна. E-mail: zdovado@ukr.net

(с) Н.M. Cтепура, Г.А. Замотаєва, І.П. Волинець продукція антитіл до рецепторів тиреотропного гормону (ТТГ), що чинять постійну стимулюючу дію на Щ3 [1, 2]. Це призводить до збільшення маси тиреоїдної тканини, гіперфункції та підвищення рівня тиреоїдних гормонів $\mathrm{T}_{3}$ (трийодтироніну) та $\mathrm{T}_{4}$ (тироксину). ДТЗ супрово- 
джується розвитком тиреотоксикозу, який клінічно проявляється підвищеними збудливістю та дратівливістю, зниженням маси тіла, серцебиттям, пітливістю, задухою, субфебрильною температурою [3].

Сьогодні існують три підходи до лікування ДТЗ: консервативний, оперативний і радіологічний. Вибір методу лікування залежить від тяжкості захворювання, ступеня збільшення та розташування зоба, розвитку ускладнень і супутньої патології. Метою консервативного лікування є нормалізація функціонального стану ЩЗ за допомогою тиреостатичних препаратів і досягнення імунної ремісії. Головна проблема медикаментозного лікування ДТЗ - часті рецидиви та труднощі їх прогнозування. Частота рецидивів упродовж перших п'яти років після відміни консервативної терапії становить 50-60\% [4, 5].

Субтотальне видалення ЩЗ показано за відсутності стійкого ефекту від консервативної терапії, за зоба четвертого або п'ятого ступеня, тяжкого тиреотоксикозу, наявності протипоказань до застосування тиреостатиків, хвороб крові тощо. Проте досить часто (35-40\% випадків) і після хірургічного лікування ДТЗ розвиваються рецидиви захворювання. Тому важливим напрямком практичної медицини є вибір оптимальних способів лікування ДТЗ, одним з яких є терапія радіоактивним йодом. Основними перевагами радіойодотерапії (РЙТ) є їі неінвазійність, відсутність виражених больових відчуттів, відсутність імовірності розвитку ускладнень, характерних для хірургічного лікування, зокрема тиреотоксичного кризу. Крім цього, правильний добір дози ізотопу, що застосовується для радіойодотерапії, визначає іiі досить високу ефективність.

Лікування радіоактивним йодом грунтується на здатності тканини ЩЗ накопичувати йод, необхідний для синтезу гормонів. Введення в організм хворого невеликої кількості йоду-131 призводить до руйнування тканини ЩЗ бетавипромінюванням йоду та порушення іiї функції, тобто зниження продукції тиреоїдних гормонів. Результатом лікування радіоактивним йодом може бути як нормалізація синтезу гормонів, так і його зниження (гіпотиреоз). Розвиток гіпотиреозу має більші переваги, оскільки гарантує хворому відсутність рецидиву захворювання в майбутньому. Тому наразі є тенденція до використання дещо більших активностей радіоак- тивного йоду в лікуванні ДТЗ, а швидкий розвиток гіпотиреозу вважається основною метою лікування [6, 7].

Дози ізотопу, які отримує пацієнт для лікування ДТЗ, зазвичай є не дуже великими від 8 до 15 мКі та залежать від розміру зоба та ступеня тиреотоксикозу [8, 9]. Для лікування раку ЩЗ застосовують у десять разів більші дози йоду-131. Отже, розподіл радіоактивного йоду в організмі i, відповідно, дози опромінення периферичної крові, кровотворної тканини кісткового мозку та лімфоїдних органів істотно різняться.

ЦІК є показником розвитку різних запальних процесів в організмі та маркером автоімунних захворювань. У певних публікаціях описано рівень ЦІК на тлі ДТЗ і різних методів його лікування [10]. Натомість даних щодо вмісту ЦІК у крові хворих із тиреотоксикозом після радіойодотерапії в доступній літературі не знайдено. Тому метою даної роботи було визначення кількості ЦІК у крові хворих на ДТЗ напередодні та в різні терміни після радіойодотерапії, а також порівняння отриманих даних із показниками хворих на рак ЩЗ.

\section{Матеріал і методи}

Визначено рівні ЦІК у 34 хворих на ДТЗ після першого курсу лікування радіойодом. Радіойодотерапію проводили в блоці для лікування радіофармацевтичними препаратами у відкритому вигляді ДУ «Інститут ендокринології та обміну речовин ім. В.П. Комісаренка НАМН України». Вік хворих був у межах від 22 до 67 років $(47,18 \pm 2,06)$, серед них 7 чоловіків і 27 жінок. Дози радіоактивного йоду становили від 400 МБк до 800 МБк (значення $549 \pm 20,0$ МБк).

До групи порівняння увійшли 49 хворих на рак ЩЗ без віддалених метастазів. Серед них 77,6\% становили жінки, 22,4\% - чоловіки, середній вік пацієнтів - 53,5 1,3 року, дози йоду-131 - від 2640 мБк до 6000 мБк.

Контролем була кров донорів відповідного віку та статі в кількості 23 осіб.

Рівні ЦІК визначали напередодні радіойодотерапії та на 6-у добу й через 1 і 6 місяців після курсу. Вміст ЦІК у сироватці крові визначали методом преципітації їх поліетиленгліколем із молекулярною масою 6000 (Serva) 3 наступ- 
ним вимірюванням оптичної щільності досліджуваних зразків на спектрофотометрі СФ-46 за довжини хвилі 450 нм [13]. Вміст імунних комплексів представляли в умовних одиницях $\left(\mathrm{E}_{450} \times 10^{3}\right)$.

Статистичну обробку даних проводили методом варіаційної статистики з обчисленням t-критерію Стьюдента. Різницю вважали вірогідною за $\mathrm{p}<0,05$.

Перед початком дослідження було отримано інформовану згоду від усіх пацієнтів і донорів та дозвіл від Комісії з медичної етики ДУ «Інститут ендокринології та обміну речовин ім. В.П. Комісаренка НАМН України».

\section{Результати та обговорення}

Результати визначення кількості ЦІК у крові хворих на ДТЗ і рак ЩЗ наведено в таблиці.

Як видно із результатів, наведених в таблиці, у хворих на ДТЗ і рак ЩЗ вміст ЦІК протягом усього періоду спостереження був достовірно більшим за показник контрольної групи.

Напередодні радіойодотерапії у хворих на ДТЗ кількість ЦІК була більшою, ніж у хворих на тиреоїдний рак, що, імовірно, є результатом активації гуморальної ланки імунітету та підтвердженням автоімунного генезу даного захворювання. Після радіойодотерапії динаміка змін кількості ЦІК у сироватці крові хворих на ДТЗ і рак ЩЗ мала деякі відмінності.

У пацієнтів із ДТЗ після введення радіойоду кількість ЦІК протягом усього періоду обстеження практично не змінювалася. Лише на

Таблиця. Рівень циркулюючих імунних комплексів у хворих на дифузний токсичний зоб і рак щитоподібної залози в різні терміни після радіойодотерапії $\left(\mathrm{E}_{450} \times 10^{3}\right)$

\begin{tabular}{|c|c|c|c|c|}
\hline \multirow{2}{*}{$\begin{array}{l}\text { Контроль } \\
\text { (донори) }\end{array}$} & \multirow{2}{*}{$\begin{array}{l}\text { Перед } \\
\text { введенням } \\
\text { йоду-131 }\end{array}$} & \multicolumn{3}{|c|}{ Після введення йоду-131 } \\
\hline & & 6 днів & 1 мic. & 6 мic. \\
\hline & хворі на диф & ний токсич & ий зоб (I гр & /па) \\
\hline \multirow[t]{8}{*}{$63,7 \pm 2,2$} & $96,8 \pm 5,7$ & $107,4 \pm 6,4$ & $97,2 \pm 9,4$ & $97,0 \pm 8,4$ \\
\hline & $p<0,05$ & $p<0,05$ & $p<0,05$ & $p<0,05$ \\
\hline & & $p_{1}>0,05$ & $p_{1}>0,05$ & $p_{1}>0,05$ \\
\hline & хворі на рак & итоподібно & залози (II гю & упа) \\
\hline & $89,6 \pm 2,3$ & $92,3 \pm 2,0$ & $101,7 \pm 4,6$ & $86,5 \pm 4,5$ \\
\hline & $p<0,05$ & $\mathrm{p}<0,05$ & $p<0,05$ & $\mathrm{p}<0,05$ \\
\hline & & $p_{1}>0,05$ & $\mathrm{p}_{1}<0,05$ & $p_{1}>0,05$ \\
\hline & $p_{2}>0,05$ & $\mathrm{p}_{2}<0,05$ & $p_{2}>0,05$ & $p_{2}>0,05$ \\
\hline
\end{tabular}

Примітка: $p$ - вірогідність різничі відносно групи донорів; $p_{1}$ показника перед радіойодотерапією; $p_{2}$ - між показниками хворих li ll груnu. 6-у добу спостерігали незначне зростання вмісту ЦІК - на 11,0\%. У хворих на рак ЩЗ введення лікувальних активностей йоду-131 спричинило зростання вмісту ЦІК. Якщо на 6-й день після введення радіофармпрепарату досліджуваний показник збільшився незначно, то через 1 місяць він досягнув максимуму та вірогідно перебільшив вихідний. Через півроку вміст ЦІК у сироватці крові хворих на тиреоїдний рак зменшився до вихідного значення.

Порівняння вмісту ЦІК у сироватці крові пацієнтів із ДТЗ і з раком ЩЗ у динаміці виявило достовірну різницю між групами лише в ранній термін (на 6-у добу) після радіойодотерапіі. У хворих на ДТЗ досліджуваний показник був вірогідно більшим за такий у пацієнтів, хворих на рак Щ3.

На нашу думку, високий рівень ЦІК у крові хворих на ДТЗ може свідчити про активацію продукції антитіл та дисфункцію ретикуло-ендотеліальної системи, що відповідає за виведення ЦІК із кров'яного русла. Встановлена різниця вмісту ЦІК після радіойодотерапії у хворих на ДТЗ і тиреоїдний рак, вочевидь, є наслідком застосування різних доз йоду-131: хворі з ДТЗ отримували радіойод, активність якого становила від 380 МБк до 784 МБк, тоді як активність йоду-131 у хворих на рак ЩЗ була значно більшою - від 2640 МБк до 6000 МБк.

\section{Висновки}

1. У хворих на ДТЗ напередодні радіойодотерапії та в різні терміни після введення ізотопу (до 6 місяців) було вірогідно збільшено кількість ЦІК у крові.

2. Напередодні радіойодотерапії рівень ЦІК у хворих на ДТЗ був більшим, ніж у пацієнтів із тиреоїдним раком, що може бути результатом активації гуморальної ланки імунітету та підтвердженням автоімунного генезу даного захворювання.

3. Встановлена різниця вмісту ЦІК у крові після радіойодотерапії у хворих на ДТЗ і рак Щ3, вочевидь, є наслідком введення різних активностей йоду-131.

\section{Список використаної літератури}

1. Morshed S, Latif R, Davies T. Delineating the autoimmune mechanisms in Graves' disease. Immunol Res. 2012; 54(1-3):191-203.

2. Antonelli A, Ferrari S, Corrado A, Di Domenicantonio A, Fallahi P. 
Autoimmune thyroid disorders. Autoimmun Rev. 2015;14(2):174-80.

3. Паньків BI. Захворювання щитоподібної залози. Буковинська державна медична академія. 2003; 258 с. (Pan'kiv VI. Thyroid disease. Bukovyns'ka derzhavna medychna akademiya. 2003; 258 p.).

4. Пасєчко НВ, Наумова ЛВ, Кульчінська ВМ, Джула МА. Особливості антитиреоїдної терапії хворих на дифузний токсичний зоб. Досвід використання карбімазолу. Міжнародний ендокринологічний журнал. 2015; 3 (67): 112-7. (Pasyechko NV, Naumova LV, Kul'chins'ka VM, Dzhula MA. Features of antithyroid therapy for patients with diffuse toxic goiter. Carbimazole use experience. Mizhnarodnyy endokrynolohichnyy zhurnal. 2015; 3 (67): 112-7).

5. Паньків ВІ. Синдром тиреотоксикозу. Міжнародний ендокринологічний журнал. 2012; 4 (44): 102-16. (Pan'kiv VI. Thyrotoxicosis syndrome. Mizhnarodnyy endokrynolohichnyy zhurnal. 2012; 4 (44): 102-16).

6. Елишев ВГ, Аверина НВ, Шабалина ТИ. Опыт применения радиойодтерапии тиреотоксикоза. Тюменский медицинский журнал. 2013;15(4):67-8. (Yelishev VG, Averina NV, Shabalina TI. Experience in the use of radioiodine therapy for thyrotoxicosis. Tyumenskiy meditsinskiy zhurnal. 2013;15(4):67-8).

7. Санчес МН, Горбенко АЛ, Солодянникова ОІ, Василенко IB. 3 досвіду лікування тиреотоксикозу радіоактивним йодом. Український радіологічний журнал. 2012; 3: 324-5. (Sanches MN, Horbenko AL, Solodyannykova OI, Vasylenko IV. From experience in the treatment of thyrotoxicosis with radioactive iodine. Ukrayins'kyy radiolohichnyy zhurnal. 2012; 3: 324-5).

8. Гарбузов ПИ. Радиойодтерапия заболеваний щитовидной железы (диффузный токсический зоб, рак щитовидной железы). Copyright ФГОУ «ГЦИПК». ГУ-МРНЦ РАМН.1997; 1-10. (Garbuzov PI. Radioiodine therapy of thyroid diseases (diffuse toxic goiter, thyroid cancer). Copyright FGOU «GTSIPK». GU-MRNTS RAMN.1997; 1-10).

9. Гарбузов ПИ, Дроздовский БЯ, Родичев АА, Тимохина ОВ, Подольхова НВ. Радиойодтерапия рака щитовидной железы. Практическая онкология. 2007; 8(1):42-5. (Garbuzov PI, Drozdovskiy BYa, Rodichev AA, Timokhina OV, Podol'khova NV. Radioiodine therapy for thyroid cancer. Prakticheskaya onkologiya. 2007; 8(1):42-5).

10. Геворкян АГ, Цогоев АС, Болиева ЛЗ. Сравнительная характеристика показателей иммунного статуса больных диффузным токсическим зобом и аутоиммунным тиреоидитом. Вестник новых медицинских технологий. 2007; XIY(3):155-6. (Gevorkyan AG, Tsogoyev AS, Boliyeva LZ. Comparative characteristics of the immune status of patients with diffuse toxic goiter and autoimmune thyroiditis).

11. Абазова ЗХ. Новый подход в тактике лечения субклинического гипертиреоза. Фундаментальные исследования. 2013; 3:41-6. (Abazova ZKh. A new approach to the treatment of subclinical hyperthyroidism. Fundamental'nyye issledovaniya. 2013; 3:41-6).

12. Ляшенко ЕА. Нарушения гуморального иммунитета у больных с аутоиммунными заболеваниями щитовидной железы и их коррекция полибиолоном. Український медичний альманах. 2013;16(3):98-100. (Lyashenko YeA. Humoral immunity disorders in patients with autoimmune thyroid diseases and their correction with polybiolone. Ukraîns'kiy medichniy al'manakh. 2013;16(3):98-100).

13. Haskova V, Koslik J, Riha I. Simple method of circulating immune complex detection in human sera by poliethylene glucol precipitation. Immunitasforsoh. 1978;154(4):399-406.

(Надійшла до редакції 05.08.2019р.)

\section{Уровень циркулирующих иммунных комплексов у больных диффузным токсическим зобом при лечении радиойодом}

\section{Н.Н. Степура, Г.А. Замотаева, И.П. Волынец}

ГУ «Институт эндокринологии и обмена веществ им. В.П. Комиссаренко НАМН Украины», г. Киев

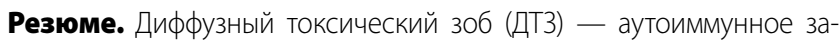
болевание, которое сопровождается стойким повышением продукции тиреоидных гормонов и диффузным увеличением щитовидной железы разной степени. Причинами развития ДТЗ являются ауто- иммунные процессы, то есть формирование агрессии против ткани собственной щитовидной железы. Целью работы было изучение влияния радиойодтерапии на количество циркулирующих иммунных комплексов (ЦИК) в крови больных ДТЗ. Материал и методы. Изучен уровень ЦИК у 34 больных ДТ3 и 49 пациентов с тиреоидным раком (группа сравнения). Уровень ЦИК определяли накануне и через 6 дней, 1 и 6 месяцев после введения йода-131. Результаты. На протяжении всего периода после радиойодтерапии содержание ЦИК у больных ДТЗ практически не менялось. Введение терапевтических активностей радиойода пациентам с раком щитовидной железы привело к увеличению уровня ЦИК с максимальным значением показателя через один месяц после введения радиофармпрепарата. Выводы. Полученная разница содержания ЦИК в крови после радиойодтерапии у больных ДТЗ и тиреоидным раком, очевидно, является следствием введения различных активностей йода-131: пациенты с ДТ3 получали радиойод, активность которого составляла От 380 МБк до 784 МБк, а больные раком щитовидной железы — от 2640 МБк до 6000 МБк

Ключевые слова: диффузный токсический 30б, тиреотоксикоз, рак щитовидной железы, радиойодтерапия, йод-131, циркулирующие иммунные комплексы.

\section{Level of circulating immune complexes in patients with diffuse toxic goiter under radioiodine treatment}

\section{N.M. Stepura, G.A. Zamotayeva, I.P. Volynets}

State Institution «V. P. Komisarenko Institute of Endocrinology and Metabolism, Natl. Acad. Med. Sci. of Ukraine», Kyiv

Abstract. Diffuse toxic goiter (DTG) is classified as an autoimmune disease that causes diffusely thyroid hyperplasia and excessive thyroid hormone overproduction. These diseases arise because of the loss of tolerance to «self» thyroid antigens in genetically susceptible individuals in association with environmental factors. The aim was to study the effect of radioiodine therapy on the content of circulating immune complexes in blood serum of patients with DTG. Material and methods. 34 patients with diffuse toxic goiter (Graves's disease) and 49 patients with differentiated thyroid cancer (comparison group) have been followed up. The CIC levels were determined one day prior to iodine-131 administration, and 6 days, 1 and 6 months after radioiodine therapy. Results. The content of immune complexes in patients with thyrotoxicosis did not change significantly throughout the observation period. lodine-131 administration at therapeutic activities to patients with thyroid cancer caused an increase the level of CEC, with a maximum value in one month after radiotherapy. Conclusion. The difference in the content of antigen-antibody complexes after radioiodine therapy in patients with DTG and thyroid cancer is obviously due to iodine-131activities: patients with thyrotoxicosis received iodine-131 doses in the range from $380 \mathrm{MBq}$ to $784 \mathrm{MBq}$, and patients with thyroid cancer — from $2640 \mathrm{MBq}$ to $6000 \mathrm{MBq}$

Keywords: diffuse toxic goiter, thyrotoxicosis, thyroid cancer, radioiodine therapy, iodine-131, circulating immune complexes. 